\title{
シロネズミの発㕕, ナトリウム排泄および 血圧に及ぼす飼料中白米水洗の影響 Effect of Washing of Rice in the Diet of Rats on Their Growth, Sodium Excretion and Blood Pressure
}

(昭 和 37 年 5 月 19 日受理)

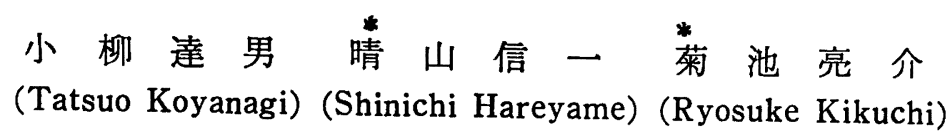

By seven successive washings of polished rice by water $90 \%$ of thiamine, $60 \%$ of pantothenic acid, $50 \%$ of riboflavin and $40 \%$ of choline were lost.

Rats fed diet containing washed rice and adequate amounts of thiamine, riboflavin, vitamin $\mathrm{B}_{6}$ and nicotinic acid showed a considerable depression in growth. Urine volume and urinary sodium output decreased and blood pressure was elevated in comparison with those fed diet containing unwashed milled rice. Supplement of pantothenic acid to the washed milled rice diet counteracted almost completely the adverse effect of washed rice diet on the sodium excretion and blood pressure.

The reason of frequent occurrence of incidence of hypertension among people consuming washed rice diet was discussed.

小楖ら1) は水洗白米 91.5 , 大豆かす 5, にんじん 1 , 炭 酸カルシウ $\Delta 0.5$, 大豆油 1 , 食塩 $1(\mathrm{~g})$ ，サイアミン $\left(B_{1}\right) 0.1(\mathrm{mg})$ よりなる飼料を与えたシロネズミの血压 は，飼料中の食塩含量を $2.5 \mathrm{~g}$ に增すと上年するが，こ れにリボフラビン $\left(\mathrm{B}_{2}\right)$, ニリン，パントテン酸 $(\mathrm{PaA})$ 又はビタミン Aを多量に添加すると血圧の上㫒が防がれ ることを報告した。

これらのビタミンのうち水溶性のものは元の白米に或 程度含まれているので水洗をしない白米ならばこれを与 えたネズミの血圧の上䄯は防がれるのではないかと考え られる。

そこでわれわれは白米の水洗によりどの程度に各種ビ タミンが失われるかを測定し，次にシロネズミの飼育試 检を行なって発育、ナトリウム排泄、アセチル化能力お よび血圧に及にす飼料中白米水洗の影锌を調べた。その 成彎を報告する。

\section{方法}

分析法: $\mathrm{B}_{1}$ はチオクローム法2)， $\mathrm{B}_{2}$ はルミフラビン法2)
コリンはライネッケ法名, $\mathrm{PaA}$ は Lactb. arabinosusに よる微生物法4),ナトリウム(Na)は炎光分析法”)によ。 た。

フセチル化能の検定 : Riggs ${ }^{6)}$ の方法によりスルファニ ルアミドを注射してこれが尿中アセチル化されて排泄さ れる率を測定した。

血圧の測定：Williams らクの方法によった。

$$
\text { 結果 }
$$

（1）水洗による白米の $\mathrm{B}_{1}, \mathrm{~B}_{2}$, コリンおよび $\mathrm{PaA}$ の 減少

市販白米 $1 \mathrm{~kg}$ に $3 l$ の水道水を加え一般家庭で行な5 如く手で毘拌し，その水を傾斜して去ったものから試料 を採取して 1 回水洗の分析材料とした。傾斜して除いた 水の量に等しい量の水を新しく加えて観拌水洗後に傾斜 して水を除く。これを全部で 7 回行なった。

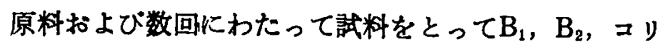
ンおよび $\mathrm{PaA}$ の定量を行なった結果第 1 表の如き成績 を得た。 
第 1 表 水洗による白米中ビタミンの減少

\begin{tabular}{|c|c|c|c|c|}
\hline \multirow{2}{*}{$\begin{array}{l}\text { 洗った } \\
\text { 回 数 }\end{array}$} & \multicolumn{4}{|c|}{ 試 料 $100 \mathrm{~g}$ 中 } \\
\hline & $\mathrm{B}_{\mathrm{t}}$ & $\mathrm{B}_{2}$ & $\mathrm{PaA}$ & コリン \\
\hline & $\gamma$ & $r$ & $\mathrm{mg}$ & $\mathrm{mg}$ \\
\hline 0 & 45.5 & 42.4 & 0.70 & 63.5 \\
\hline 1 & 32.5 & 23.2 & 0.32 & 60.6 \\
\hline 2 & 32.5 & 23.2 & 0.29 & 52.4 \\
\hline 3 & 4.8 & 23.2 & 0.28 & 40.4 \\
\hline 7 & 2.8 & 22.0 & 0.25 & 40.0 \\
\hline
\end{tabular}

これによってみるともっとも失なわれる率の大きいの は $\mathrm{B}_{1}$ で, これは 7 回の水洗で大部分失なわれ, 次が $\mathrm{PaA}$ で $2 / 3$ の損失である。 $\mathrm{B}_{2}$ は $1 / 2$, コリンは $1 / 3$ 失なわれ た。

\section{（2）ネズミ飼育試歌}

生後 1 カ月のシロネズミ(Wister 系)婎を, 水洗白米 8 涷と 5 ふ 15 , 大豆油 5 , 食塩 1 , 炭酸カルシウム $1(\mathrm{~g})$, $\mathrm{B}_{1} 0.2, \mathrm{~B}_{2} 0.2, \mathrm{~B}_{6} 0.2$, ナイアシン $2(\mathrm{mg})$ 扎よび肝油 1 滴よりなる飼料で 2 週間予備飼育したのち 3 群に分 け，3種の試験飼料を与えた。

試験飼料はいずれる $2.5 \mathrm{~g}$ の食塩を配合した高食塩飼 料である。第 1 区は予備飼育に使用した飼料中の水洗白 米を末水洗白米に替えたもの，第 2 区は水洗白米使用， 第3 区は水洗白米に $3 \mathrm{mg}$ の $\mathrm{PaA}$ を添加したものを与 えた。各区とも予備飼育のときと同じく最少必要量を満 たすに足る $\mathrm{B}_{1}, \mathrm{~B}_{2}, \mathrm{~B}_{6}$, ナイアシン扰よび肝油を補っ た。肝油は保健産業株式会社製!リパーA滴を大豆油で 100 倍に5すめたもので 1 滴中10 I. U. のビタミンAを 含有していた。

ネズミに与える飼料の量はもっとも食べる量の少ない ネズミの量に揃えた。飼料を加熱糊化するに当っては予 備飼育のときから飼料と水との比は10:13としこれ以外 の水は与えなかった。食塩含量は急に高めるとネズミが 弱ってしま5ので試験開始後 4 週間で $2.5 \%$ 5 にるよ5 に除々に高めた。

試験期間は15週間で最後の週に連続 3 日間 $\mathrm{Na}$ の尿中 排泄量と体内のアセチル化能を測定し，血圧を測り副㹂 重量を科量した。

体重変化は第 2 表に示す如くで未水洗米区のネズミが $121.4 \mathrm{~g}$ の体重增加を示したのに対し，皮洗米区のは, $68.6 \mathrm{~g}$ で著しく劣りこれに $\mathrm{PaA}$ を補った区では10 $3.0 \mathrm{~g}$ になり明らかに 水洗米区には $\mathrm{PaA}$ の不足があり これが発育に影響していることを示した。

尿中の $\mathrm{Na}$ 排泄，アセチル化能拉よび血王の測定結果 は第 3 表の如くである。
第 2 表 未水洗米，水洗米あるいは水洗米 $+\mathrm{PaA}$ を与 えたネズミの体重変化（6 頭平均体重）

\begin{tabular}{l}
\hline 飼 料 \\
\hline
\end{tabular}

* : 標準偏差

第 3 表 $\mathrm{Na}$ 排泄, アセチル化能力および血圧に及汸す 水洗米の影響（各区 4 頭平均）

\begin{tabular}{|c|c|c|c|}
\hline 飼 & 末水洗米 & 水 洗 米 & $\begin{array}{l}\text { 水 洗 米 } \\
+\mathrm{PaA}\end{array}$ \\
\hline 1 日の尿量 （cc） & $8.5 \pm 2.5$ & $2.5 \pm 1.8$ & $6.3 \pm 1.5$ \\
\hline 1 日の $\mathrm{Na}$ 排泄 $(\mathrm{mg})$ & $66.3 \pm 12.8$ & $36.6 \pm 28.9$ & $63.9 \pm 23.4$ \\
\hline アセチル化能 （\%) & $70.2 \pm 4.5$ & $65.7 \pm 5.2$ & $70.7 \pm 2.4$ \\
\hline 血 王 ( $\mathrm{Hg} \mathrm{mm})$ & $130.4 \pm 2.3$ & $140.5 \pm 2.9$ & $133.0 \pm 1.8$ \\
\hline 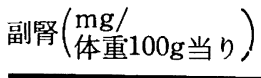 & $17.4 \pm 0.4$ & $22.3 \pm 9.7$ & $18.6 \pm 2.1$ \\
\hline
\end{tabular}

尿量は未水洗米区のネズミは多いが水洗米区では著し く減少し $\mathrm{PaA}$ を添加すると回復してくる。Na の排洴 量は，尿量と比例しており未水洗米がもっと多く排泄 するのに対し水洗米区ではその半量位しか排泄しない。 $\mathrm{PaA}$ を補うと未水洗米区に近い排泄をした。

スルファニルアミドのアセチル化能力は各区共正常值 の範用内にあるが水洗米区だけ少し低い傾向を示した。 血圧は未水洗米区のネズミに比し水洗米区のすのは高 い値を示し水洗米にPaAを補らと血圧上年が阻止され未 水洗米に近い值に下がった。体重に対する副腎の割合は 末水洗米が小さく，水洗米区では肥大し，PaAを補なら と末水洗米区の值に似て小さくなった。

\section{考察}

米を水洗することにより水溶性ビタミンの失なわれる ことが多いが，このビタミンの中でもっとも流亡事の大 きいのはB ズミに血王の上昇を起こさないことを Calder ${ }^{8)}$ が認め ている。これに対して，米中に含有される量からいって 血圧に及ぼするのとして重要視すべきは $\mathrm{PaA}$ でら。

$\mathrm{PaA}$ は白米中にあったるのが水洗によって約 $1 / 3$ K淡 
少し，本実験成結の示すところによれば水洗米は $\mathrm{B}_{1}, \mathrm{~B}_{2}$, B。 およびナイアシンという他の水溶性ビタミンを少量 禣なってす発有，尿量，Na 排泄およびアセチル化能に拉 いて未水洗米化比して劣り，血圧の上䄯子未水洗米より 著しかった。水洗米にこれらビタミンのほかに $\mathrm{PaA}$ を 補な5とはじめて尿量，Na 排泄，尿量およびアセチル 化能が增し血压の上年る阻止された。それ仲え水洗によ る $\mathrm{PaA}$ の損失は見逃すことはできない大きな影䍌を動 物仅及すということができよう。

高食塩飼料によるネズミの血圧上界は $\mathrm{Na} か ゙$ 体内に 蓄頪することに関係するとされているが9)，水洗米区の ネズミの尿および $\mathrm{Na}$ の排泄量の減少とこの区のネズ ミに副腎の肥大があることから考えて，水洗米区では $\mathrm{PaA}$ 不足による副腎器能の低下がありこれが $\mathrm{Na}$ の排泄 を阻害し血圧上年を著しくしたものと考えられる。 小即ら ${ }^{10)}{ }^{11}$ は高食塩飼料を与えたネズミ肝臓中 $\mathrm{PaA}$ 含量は普通洪度の食塩含有飼料のものに比べて約 $2 / 3$ に 減少し、アセチル化能す低下することを報告している。 またこのような高食塩飼料に $\mathrm{B}_{2}, コ$ コン、ビタミンAあ るい恃 $\mathrm{PaA}$ を多量に加えると無添加区にくらべ Naの 排泄が多くなるので，これがこれらビタミンの血圧上年 阻止作用と関係あろらと考えた。

わが国では一般に白米は水洗後に煮沸しているが，こ の办洗による $\mathrm{PaA} ， \mathrm{~B}_{2}$ 扰よびョリンの不足ということ が食塩過剩拱取とともにわれわれに高血圧症の多い原因 となっているのではないかと考えられる。

木村ら ${ }^{12) 13)}$ は岩手県の白米を主食とする水田地帯, 麦 やとェを主食とする山村; 米, 麦と魚を撕取する漁村の 3 地帯にわたって30才以上のすの 628 人について高血圧 症の発現率を調査した結果それぞれ47.5,29.2および11. 3(\%)であって白米㩒取地帯に著しい高率を認めた。し かしその 1 日の食塩消費量をみると水田地帯 25.2 , 山 村29.3および漁村28.3( $\mathrm{g})$ であって 3 地区で大差なくも しろ水田地帯が少ない傾向にあった。食塩の揕取量が多 いと血压が高くなるから山村の方が高くなりそうなるの であるが事実はこれに反し水田地帯よりる山村, 漁村に 高血压が少ない。これは山村, 漁村で消費する麦やヒェ には水洗米に比べて PaA が多いことが原因ではないで あろらか。

海村ではビタミン B類のほかにさらに魚類や海藻の掑 取があるので一㕣血圧上升防止によい影響を及はてててい るのであろう。魚肉中にはメチオニンが多いが小楖14) は 水洗白米食にメチオニンを添加することにより高食塩に よるネズミの血圧上年を防ぐことを認め，海藻について はコンプを飼料中に $3 \%$ 含有させることにより，ネズミ の血压上䄯を阻止する傾向があることを報告した ${ }^{15) 。 そ ~}$
れはともかくとして米を精白するのに砂を使用しなくな った今日では米は洗わずに食べるべきものだと考党られ る。そうすれば白米食地帯の高血压症発生を減少させる ことができよう。

摘 要

（1）白米を 3 回水洗主ることにより $\mathrm{B}_{1}$ の $90 \%, \mathrm{PaA}$ の $60 \% ， \mathrm{~B}_{2}$ の50\%およびコリンの40\%が失なわれた。

（2）水洗白米を配合した飼料に $\mathrm{B}_{1}, \mathrm{~B}_{2}, \mathrm{~B}_{8}$ 扰よびナイア シンを補なってもこれを与えたネズミの発育は未水洗 米飼料に劣り血压は上䄯する。上記ビタミンとともに $\mathrm{PaA}$ 補ならとはじめて発育, Naの排泄能力は大部分 回復し, 血圧も未水洗米のものと等しくなった。

（3）白米消費地带に高血圧患者が多い原因の一つは白米 を水洗するためビタミン B 類の不足が起き易いためで あろら。

本研究を行ならにあたり実験の補助をされた渡辺真由 美君に感謝する。

\section{文献}

1) 小柳達男, 晴山信一: 岩手大学農学部報告, 2, 177 (1955)

2 ) 藤田秋治 : ビタミンの化学的定量法, 誠文堂新光社 (1951)

3) Jacobi, H.P., et al. : J. Biol. Chem., 138, 571 (1941)

4 ) 酒井平一: ビタミン 9，549 (1955)

5 ) A.S.T.M. Special Technical Publication, No. 116, Symposium on Flame Photometry (1951)

6 ) Riggs, T.R. : J. Biol.Chem., 172, 539(1948)

7) Williams, T. R. et al., J. Clin. Invest., 18, 373 (1939)

8 ) Calder, R. M. : J. Exp. Med., 76, 1 (1942)

9) Sapirstein, L. A., et al. : Proc. Soc. Exptl. Biol. Med., 73, 82 (1950)

10）小柳達男, 晴山信一, 菊池亮介：ビタミン，21, 247 (1960)

11）小柳達男，晴山信一：ビタミン，17，142（1959）

12) 木村武 5 :岩手医誌, 5,155 (1954)

13) 木村武ら：岩手医誌， 8，293 (1957)

14）小柳達男: 本誌, 14, 503 (1962)

15）小柳達男：栄養・食糧学会大会講演（1961）

(東北大学膿学部栄盖化学研究室) * (岩手大学農学部柴養化学研究室) 